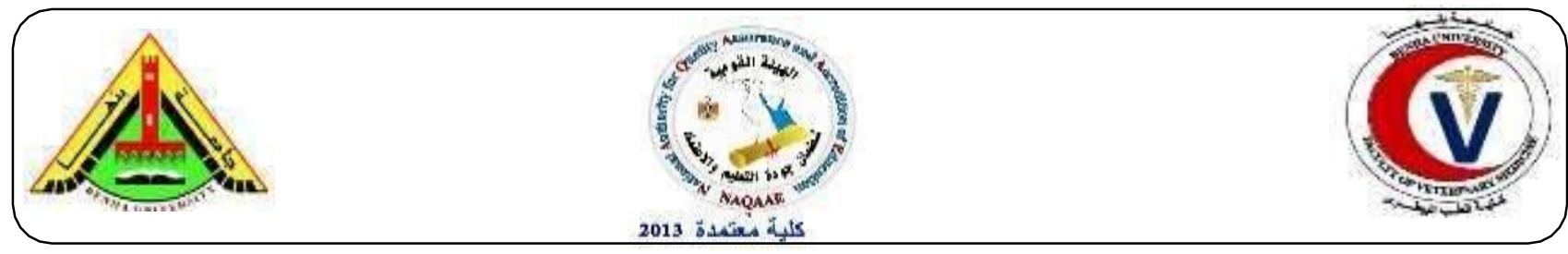

\title{
Bacteriological and molecular studies on antibiotic resistant Escherichia coli isolated from meat and its products in Kaliobia, Egypt
}

\author{
${ }^{1}$ Ashraf, A. Abd El- Tawab., ${ }^{2}$ Ahmed A. Maarouf and Ahmed M.A. El-Sayed \\ ${ }^{1}$ Bacteriology, Immunology and Mycology Dep., Faculty of Veterinary Medicine .Benha University . \\ ${ }^{2}$ Animal Health Research Institute;Benha branch
}

\section{A B STRACT}

The present study was performed on 175 random samples (about $250 \mathrm{~g}$ for each) of fresh meat and meat products viz: Sausage, beef burger, luncheon and Kofta (35 for each), were collected from different shops at Kaliobia Governorate, Egypt, for detection of E. coli and phenotypic characterization as well as virulence and antibiotic resistant genes in them. Bacteriological examination indicated the isolation of $11(6.3 \%)$ isolates of $E$. coli from 175 samples as kofta, sausage samples ( $3=8.6 \%$ for each) followed by fresh meat, beef burger samples $(2=5.7 \%$ for each) and luncheon $(1=2.9 \%)$. Accordingly, $E$. coli strains were serotyped as one O26:H11 from beef burger samples; four $\mathrm{O}_{55}: \mathrm{H}_{7}$ (one from each samples of fresh meat, luncheon, kofta and sausage); two $\mathrm{O}_{111}: \mathrm{H}_{4}$ (one from each samples fresh meat and kofta); one $\mathrm{O}_{119}: \mathrm{H}_{4}$ from sausage samples and three $\mathrm{O}_{125}: \mathrm{H}_{18}$ (one from each samples beef burger, kofta and sausage). The antibiotic sensitivity profile revealed that the isolated E. coli strains were highly resistant for methicillin and oxacillin followed by amoxicillin; ampicillin; oxytetracycline; streptomycin; erythromycin; Nalidixic acid. Meanwhile, they were highly sensitive to enrofloxacin and gentamycin followed by norfloxacin; cefotaxime and ciprofloxacin. PCR declared that $\boldsymbol{e a e} \mathbf{A} ; \boldsymbol{b l a T E M}$; $\boldsymbol{t e t A}(\mathrm{A})$ and aada 1 genes were amplified in all four studied E. coli strains giving product of $248 \mathrm{bp} ; 516 \mathrm{bp} ; 576 \mathrm{bp}$ and $484 \mathrm{bp}$, respectively. The study concluded that; antibiotic resistances $E$. coli is meat-borne pathogen of public health important.

Key words: Meat products, E. coli, antibiotic resistant genes

(http://www.bvmj.bu.edu.eg)

BVMJ-36(2): 335-344, 2019)

\section{INTRODUCTION}

Meat and meat products serve as important source of proteins for humans. However, recently the emerging antibiotic resistant foodborne pathogens combined with the injudicious use of antibiotics in animals bears considerate public health threats worldwide (Messele et al., 2017). Escherichia coli is commonly non-virulent but some strains have adopted pathogenic or toxigenic virulence factors that make them virulent to human and animals. It has become recognized as a serious food borne pathogen and has been associated with numerous out breaks of disease resulting from contaminated meat products (Gi et al., 2009 and Datta et al., 2012). Pathogenic E. coli strains have been divided into intestinal pathogenic $E$. coli and extra intestinal pathogenic E. coli (ExPEC) depending on the location of the infection they are causing. EPEC strains are responsible for a variety of infections, including bacteremia, urinary tract infections, neonatal meningitis, pneumonia, deep surgical wound infections, endovascular infections, vertebral osteomyelitis, and septicemia (Russo and Johnson, 2000 and Kaper et al., 2004).

The wide spread and imprudent use of antibiotics in food animals is thought to be 
accountable for the emergence and wider spreading of antimicrobial resistant (AMR) bacteria in humans (Aslam et al., 2009 and Messele et al., 2017). Antimicrobial resistant may be acquired or intrinsic resistance. Acquired antibiotic resistance, in which a previously sensitive bacterium becomes resistant and the majority of them are propagated through horizontal or lateral gene transfer between bacteria often due to the polymicrobial nature of infections and proximity of pathogens (Rodríguez et al., 2013 and Juhas, 2015). In addition; intrinsic resistance relates to the unique physiological properties of a microorganism, in which their metabolic activity is substantially unaffected by the presence of an antimicrobial compound. Such resistances are generally chromosomally encoded, and are typically responsible for observed differences in resistance observed between genera, species and strains of bacteria. It can be associated with differences in cell wall structures, the ability to pump antimicrobial compounds out of the bacterial cell using efflux pumps, or the production of enzymes capable of inactivating antimicrobial compounds within the bacterial cell (Russell, 2001 and Gilbert and McBain, 2003). Consumption of contaminated and/or uncooked meat poses the risks of acquiring foodborne E. coli strains (Frye and Jackson, 2013) causing a serious public health hazard. Such strains easily harbor antibiotic resistant genes from one another. This is because genes encoding AMR determinants that are carried on mobile genetic elements such as plasmids and transposes of some bacterial strains could be transferred to other bacteria strains during contact causing a threat to cure acute infections in man and animals (Van den Bogaard and Stobberingh, 2000).

Beside the antimicrobial resistance among $E$. coli strains, the pathogenicity of them could be attributed to their virulence factors including those encoding for adhesions (F1, P, and stg fimbriae, curli, and eaeA); anti-host defense factors (ompA, iss, lipopolysaccharide, and $\mathrm{K} 1$ ); iron acquisition systems (aerobactin, Iro proteins, yersiniabactin, and the Sit iron acquisition locus); auto transporters ( $t s h$, vat and $\operatorname{aat} \mathrm{A})$; the phosphate transport system, sugar metabolism, and the ibe A protein (Germon et al., 2005; Zhao et al., 2009; BisiJohnson et al., 2011; Le Bouguenec and Schouler, 2011 \& Van der and Bragg, 2012).
As food-borne bacteria specially antimicrobial resistant ones constitutes serious problems for consumers, therefore, the present study was conducted to detect E. coli in meat and meat products (luncheon; kofta; beef burger and sausage) at Kaliobia Governorate, beside the phenotypic characterization of the isolates and determination of virulence and their antibacterial resistant genes.

\section{MATERIALS AND METHODS}

\subsection{Samples}

A total of 175 random samples (about $250 \mathrm{~g}$ for each) of fresh meat and meat products viz: Sausage, beef burger, luncheon and Kofta (35 for each), were collected from different shops at Kaliobia Governorate

\subsection{Bacteriological examination}

Twenty five grams of each sample were prepared for bacteriological examination according to APHA (2001).

\subsection{Isolation and identification of E. coli (Quinn et al., 2002)}

One $\mathrm{ml}$ of prepared sample was inoculated into nutrient broth and incubated aerobically at $37^{\circ} \mathrm{C}$ for 12 hours. A loopful from incubated nutrient broth was streaked on MacConkey's agar plates and incubated for 24 hours at $37^{\circ} \mathrm{C}$. Suspected lactose fermented colonies were picked up and streaked on the following media: Eosin methylene blue (EMB); Brilliant Green agar (BG) and Xylose Lysine Deoxycholate (XLD) agar and incubated for another 24-48 hours at $37^{\circ} \mathrm{C}$. Suspected colonies (colonies with metallic green sheen on EMB; yellow colonies on BG and bright yellow colonies and agar on XLD) were picked up and kept in Semi-solid nutrient agar. The purified isolates of $E$. coli were morphologically identified by Gram stain; biochemical tests and serologically by slide agglutination test using E. coli antisera of DENKA SEIKEN CO., LTD.TOKYO, Japan according to Edward and Ewing (1972) and Quinn et al. (2002).

\subsection{In-Vitro anti-microbial sensitivity test}

The isolated $E$. coli strains were subjected to the sensitivity test against different antibiotics) using the disc and agar diffusion method 
(Koneman et al., 1997) and interpretation of results were carried out according to NCCLS (2007).

\subsection{Detection of Virulence and antibiotic resistant genes of E. coli by PCR}

PCR was applied by using four sets of primers for detection of four virulence and antibiotic resistant genes that may play a role in virulence of $E$. coli. These genes were intimin or $E$. coli attaching and effacing gene (eaeA); $\beta$ lactamase ampicillin resistance gene (blaTEM); tetracycline resistant $\mathrm{A}$ gene $(\operatorname{tet} \mathrm{A})$ and streptomycin resistant gene (aada1).

It was applied on four random isolated $E$. coli that showed antibiotic resistant by disk diffusion method to the same studied strains following QIAamp ${ }^{\circledR}$ DNA Mini Kit instructions (Catalogue no. 51304), Emerald Amp GT PCR mastermix (Takara) with Code No. RR310A and $1.5 \%$ agarose gel electrophoreses (Sambrook et al., 1989) using the Primers sequences, target genes, amplicons sizes and cycling conditions showed in Table (2).

\section{RESULTS}

The recorded results in Table (3) revealed a total of $11(6.3 \%)$ isolates of E. coli were recovered from 175 samples and were isolated from, kofta, sausage samples ( $3=8.6 \%$ for each) followed by fresh meat, beef burger samples $(2=5.7 \%$ for each) and luncheon $(1=2.9 \%)$.

The recovered isolates are Gram-negative, medium sized rods, arranged singly, pairs and groups and motile. They grow well on different media and showed rounded, non-pigmented colonies on Nutrient agar medium, while on MacConkey's agar medium showed rounded, non-mucoid bright pink colonies (lactose fermenter) on the surface of the medium. On Eosin methylene blue agar (EMB) showed a distinctive greenish metallic sheen colonies; yellow colonies on Brilliant Green agar (BG) and bright yellow colonies and agar on Xylose Lysine Deoxycholate (XLD) agar.

The results of biochemical identification showed that, all isolates had characteristic biochemical reaction to be $E$. coli, where, all the 11 isolates were positive for indole test; Methyl red test; catalase test; sugar fermentation test; nitrate reduction test; Eijkman test. . Meanwhile, they were negative for oxidase; Voges-Proskauer; Urease; citrate utilization and gelatin hydrolysis tests. The results of serological examination revealed that, E. coli strains were typed as one O26:H11 (9.1\%) from beef burger samples; four O55:H7 (36.4\%) from fresh meat, luncheon, kofta and sausage samples; two O111:H4 (18.2\%) from fresh meat and kofta samples; one O119:H4 (9.1\%) from sausage samples and three O125:H18 (27.3\%) from beef burger, kofta and sausage samples.

In-vitro sensitivity test (Table, 4) revealed that the $E$. coli isolates were highly resistant for methicillin and oxacillin (90.9\%) followed by amoxicillin; ampicillin and oxytetracycline (81.8\% for each); streptomycin $(72.7 \%)$ and erythromycin, Nalidixic acid (63.6\% for each). Meanwhile, they were highly sensitive to enrofloxacin and gentamycin (90.9\%) followed by norfloxacin $(81.8 \%)$ and cefotaxime, ciprofloxacin ( $72.7 \%$ for each). Moreover, they were intermediate sensitive to trimethoprim/ sulphamethoxazol (63.6\%).

PCR results showed that, eaeA; blaTEM; tetA (A) and aada 1 genes were amplified in all four studied E. coli strains giving product of $248 \mathrm{bp}$; 516 bp.; 576 bp. and 484 bp., respectively as shown in Fig. (1-4).

Table (1): Antisera used in serological identification of $E$. coli

\begin{tabular}{lccccccc}
\hline Polyvalent Sera & \multicolumn{7}{c}{ Monovalent sera } \\
\hline Polyvalent 1 & O1 & O26 & O86a & O111 & O119 & O127a & O128 \\
Polyvalent 2 & O44 & O55 & O125 & O126 & O146 & O166 & \\
Polyvalent 3 & O18 & O114 & O142 & O151 & O157 & O158 & \\
Polyvalent 4 & O6 & O27 & O78 & O148 & O159 & O168 & \\
Polyvalent 5 & O20 & O25 & O63 & O153 & O167 & & \\
Polyvalent 6 & O8 & O15 & O115 & O169 & & & \\
Polyvalent 7 & O28ac & O112ac & O124 & O136 & O144 & & \\
Polyvalent 8 & O29 & O143 & O152 & O164 & & & \\
\hline
\end{tabular}


Table (2): Oligonucleotide primers sequences source Metabion (Germany)

\begin{tabular}{|c|c|c|c|c|}
\hline $\begin{array}{l}\text { Target } \\
\text { M.O. }\end{array}$ & Gene & $\begin{array}{l}\text { Primer sequence } \\
\qquad\left(5^{\prime}-3^{\prime}\right)\end{array}$ & $\begin{array}{c}\text { Length of } \\
\text { amplified } \\
\text { product }\end{array}$ & Reference \\
\hline \multirow[t]{4}{*}{ E. coli } & $\operatorname{Tet} A(A)$ & $\begin{array}{l}\text { GGTTCACTCGAACGACGTCA } \\
\text { CTGTCCGACAAGTTGCATGA }\end{array}$ & 576 bp. & $\begin{array}{l}\text { Randall } \text { et al. } \\
, 2004\end{array}$ \\
\hline & Aada1 & $\begin{array}{l}\text { TATCAGAGGTAGTTGGCGTCAT } \\
\text { GTTCCATAGCGTTAAGGTTTCATT }\end{array}$ & 484 bp. & \\
\hline & blaTEM & $\begin{array}{l}\text { ATCAGCAATAAACCAGC } \\
\text { CCCCGAAGAACGTTTTC }\end{array}$ & 516 bp. & $\begin{array}{l}\text { Colom et al., } \\
\quad 2003\end{array}$ \\
\hline & $e a e A$ & $\begin{array}{l}\text { ATG CTT AGT GCT GGT TTA GG } \\
\text { GCC TTC ATC ATT TCG CTT TC }\end{array}$ & 248 bp. & $\begin{array}{l}\text { Bisi-Johnson et } \\
\quad \text { al., } 2011\end{array}$ \\
\hline
\end{tabular}

Table (3): Prevalence of $E$. coli strains in the examined samples (n=35 for each sample)

\begin{tabular}{lll}
\hline \multicolumn{1}{c}{ Samples } & \multicolumn{2}{c}{ E. coli strains } \\
& NO. & $\%^{*}$ \\
\hline Fresh meat & 2 & 5.7 \\
luncheon & 1 & 2.9 \\
Kofta & 3 & 8.6 \\
Beef Burger & 2 & 5.7 \\
Sausage & 3 & 8.6 \\
Total (175) & 11 & 6.3 \\
\hline * Percentage in relation to total No. of each examined samples (35 for each).
\end{tabular}

Table (4): In-Vitro anti-microbial Sensitivity test for isolated E. coli

\begin{tabular}{lcccccccc}
\hline \multicolumn{1}{c}{ Antimicrobial agents } & Disk & \multicolumn{3}{c}{ Sensitive } & \multicolumn{3}{c}{ Intermediate } & \multicolumn{3}{c}{ Resistant } \\
& concentrations & No. & $\%$ & No. & $\%$ & No. & $\%$ & $\mathrm{AA}$ \\
\hline Amoxicillin & $25 \mu \mathrm{g}$ & 1 & 9.1 & 1 & 9.1 & 9 & 81.8 & $\mathrm{R}$ \\
Ampicillin & $20 \mu \mathrm{g}$ & 1 & 9.1 & 1 & 9.1 & 9 & 81.8 & $\mathrm{R}$ \\
Cefotaxime & $30 \mu \mathrm{g}$ & 8 & 72.7 & 2 & 18.2 & 1 & 9.1 & $\mathrm{~S}$ \\
Ciprofloxacin & $5 \mu \mathrm{g}$ & 8 & 72.7 & 3 & 27.3 & 0 & 0.0 & $\mathrm{~S}$ \\
Enrofloxacin & $5 \mu \mathrm{g}$ & 10 & 90.9 & 0 & 0.0 & 1 & 9.1 & $\mathrm{~S}$ \\
Erythromycin & $15 \mu \mathrm{g}$ & 2 & 18.2 & 2 & 18.2 & 7 & 63.6 & $\mathrm{R}$ \\
Gentamicin & $10 \mu \mathrm{g}$ & 10 & 90.9 & 0 & 0.0 & 1 & 9.1 & $\mathrm{~S}$ \\
Methicillin & $5 \mu \mathrm{g}$ & 0 & 0.0 & 1 & 9.1 & 10 & 90.9 & $\mathrm{R}$ \\
Nalidixic acid & $30 \mu \mathrm{g}$ & 3 & 27.3 & 1 & 9.1 & 7 & 63.6 & $\mathrm{R}$ \\
Norfloxacin & $10 \mu \mathrm{g}$ & 9 & 81.8 & 2 & 18.2 & 0 & 0.0 & $\mathrm{~S}$ \\
Oxacillin & $1 \mu \mathrm{g}$ & 0 & 0.0 & 1 & 9.1 & 10 & 90.9 & $\mathrm{R}$ \\
Oxytetracycline & $30 \mu \mathrm{g}$ & 1 & 9.1 & 1 & 9.1 & 9 & 81.8 & $\mathrm{R}$ \\
Streptomycin & $\mathrm{S} / 10$ & 1 & 9.1 & 2 & 18.2 & 8 & 72.7 & $\mathrm{R}$ \\
Trimethoprim/ & & 2 & 18.2 & 7 & 63.6 & 2 & 18.2 & $\mathrm{IS}$ \\
Sulphamethoxazol & $23.75) \mathrm{mcg}$ & & & & & & & \\
\hline
\end{tabular}


No.: Number of isolates

AA: Antibiogram activity

$\%$ Percentage in relation to total number of isolated $E$. coli (11)

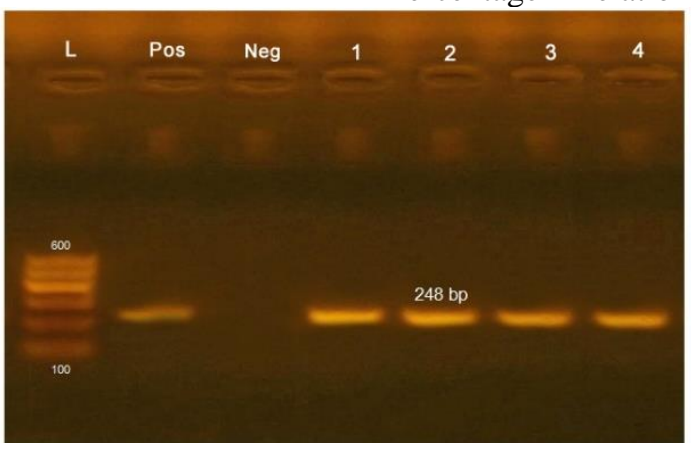

Fig. (1): Agarose Gel electrophoresis of Intiman or $E$. coli attaching and effacing (eaeA) gene. Lane L: 100-600 bpDNA Ladder.

Neg.: Negative control.

Pos.: Positive control (at 248 bp).

Lane 1-4: E. coli (Positive).

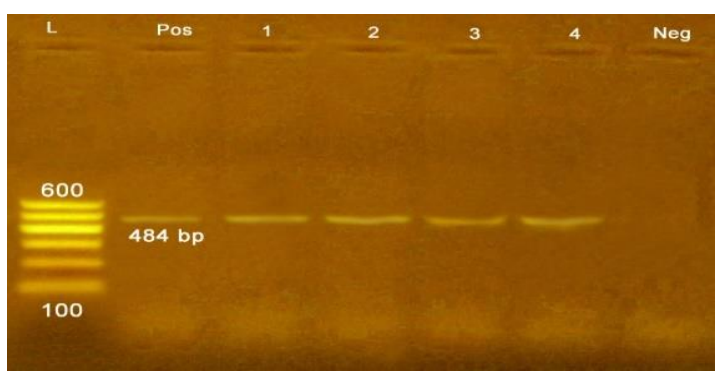

Fig. (3): Agarose Gel electrophoresis of tetracycline resistant (tet $\mathbf{A}(\mathbf{A})$ gene.

Lane L: 100-600 bp DNA Ladder.

Neg.: Negative control.

Pos.: Positive control (at 576 bp).

Lane 1 - 4: E. coli (Positive).

\section{DISCUSSION}

Escherichia coli is one of the most important bacterial pathogens in meat and its products that are responsible for food-borne infections, illness and death all over the world especially antimicrobial resistant ones (Binsy et al., 2016). The results of bacteriological examination of examined samples (Table, 3 ) revealed that $E$. coli were isolated from, kofta, sausage samples (8.6\% for each), fresh meat, beef burger samples (5.7\% for each) and luncheon (2.9\%). Nearly similar results were obtained by Abd ElSalam-Azza (2014); Armany et al. (2016) ; Tarabees et al. (2015) and El-Rais, Eman(2018).Meanwhile, these results were disagreed with those of Phillips et al. (2006); Nychas et al. (2008); Abdaslam et al. (2014); Gwida et al. (2014); Abd El-Tawab et al. (2015) ; Adwan et al. (2015) and Ramadan (2015) who isolated $E$. coli from raw meat and meat

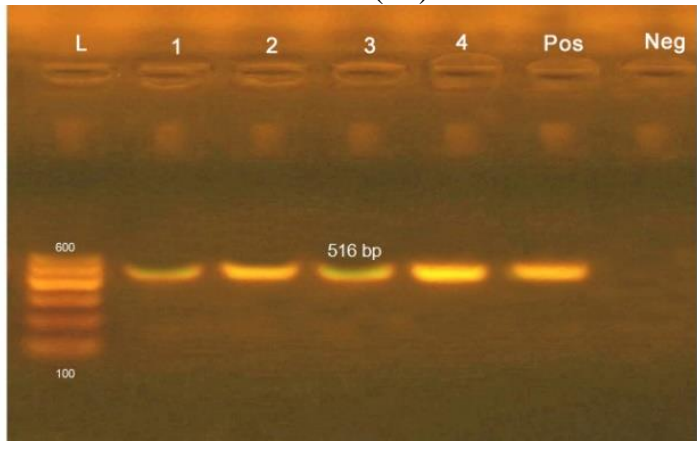

Fig. (2): Agarose Gel electrophoresis of $\beta$ lactamase ampicillin resistance gene (blaTEM). Lane L: 100-600 bp DNA Ladder. Neg.: Negative control.

Pos.: Positive control (at 516 bp).

Lane 1 - 4: E. coli (Positive).

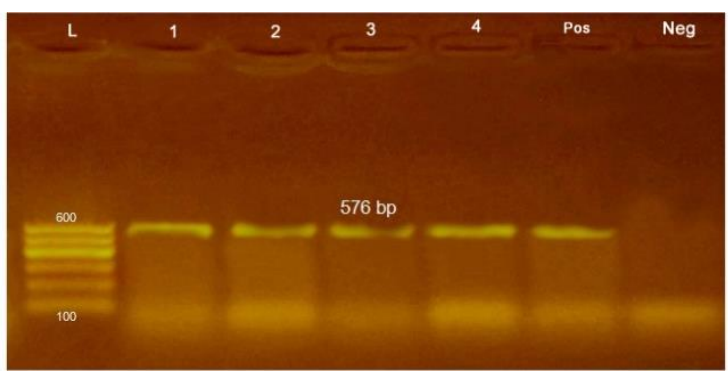

Fig. (4): Agarose Gel electrophoresis of streptomycin resistant (aada1) gene.

Lane L: 100-600 bp DNA Ladder.

Neg.: Negative control.

Pos.: Positive control (at $484 \mathrm{bp}$ ).

Lane 1 -4: E. coli (Positive).

products with high incidence. In addition, the results were disagreed with Wehab and Hegazy (2007) who could not isolate $E$. coli from beef burger samples with Siriken et al. (2006) who failed to isolate $E$. coli from beef sausage samples.

The colonial appearance and the biochemical profile of E. coli isolated was similar to those previously reported such as the fermentation of certain sugars or enzymatic reaction (Burbutashvili et al., 2007; Raji et al., 2007 and Surendraraj et al., 2010). In addition, the results of serological examination revealed that, $E$. coli strains were typed as one O26:H11 (9.1\%) from beef burger samples; four O55:H7 (36.4\%) from fresh meat, luncheon, kofta and sausage samples; two O111:H4 (18.2\%) from fresh meat and kofta samples; one O119:H4 (9.1\%) from sausage samples and three O125:H18 (27.3\%) from beef burger, kofta and sausage samples. These results came in harmony with 
those of Kalchayanand et al. (2012); Mansour (2013); Mohammed et al. (2014); Abd ElTawab et al.( 2015) and Tarabees et al. (2015) who detected the same serotypes of $E$. coli from meat and meat product samples.

In- vitro sensitivity tests for the isolated $E$. coli (Table, 4) showed that, they were highly resistant for methicillin and oxacillin followed by amoxicillin; ampicillin; oxytetracycline; streptomycin; erythromycin and Nalidixic acid. Meanwhile, they were highly sensitive to enrofloxacin and gentamycin followed by norfloxacin; cefotaxime and ciprofloxacin. Moreover, they were intermediate sensitive to trimethoprim/ sulphamethoxazol. Nearly similar were obtained by Altalhi et al. (2010); Li et al. (2011); Amosun et al. (2012); Zhao et al. (2012) and Abd El-Tawab et al. (2015). Moreover, the results proved that multiple antibiotic resistances are widely spread among isolated strains of E. coli. These observations agreed with the reports of Raji et al. (2007). It is of serious concern because these drugs are still considered the most recommended for the treatment of colibacillosis in both animal and human. In addition, antibiotic resistance in $E$. coli is of particular concern because it is the most common Gram-negative pathogen in humans, the most common cause of urinary tract infections, a common cause of both community and hospital-acquired bacteremia, as well as a cause of diarrhea(Kaper et al., 2004) .In addition, resistant E. coli strains have the ability to transfer antibiotic resistance determinants not only to other strains of $E$. coli, but also to other bacteria within the gastrointestinal tract and to acquire resistance from other organisms(Österblad et al., 2000).

The PCR technique is capable of identifying the pathogenic $E$. coli isolates based on the fact that virulence and antibiotic resistant genes varies not only among different species but also among strains of the same species. Thus, numerous studies have been conducted to identify virulence factors and antibiotic resistant genes of isolated E. coli strains (Kaper et al. ,2004; Ryu et al. ,2012 and Ahmed and Shimamoto, 2015). These genes were intimin or $E$. coli attaching and effacing gene (eaeA); $\beta$ lactamase ampicillin resistance gene (blaTEM); tetracycline resistant A gene (tetA(A) and streptomycin resistant gene (aada1). The results of PCR cleared that, eaeA; blaTEM; tet A(A) and aada 1 virulence genes were detected in all 4 studied strains.
Regarding to the E. coli attaching and effacing eaeA gene, the results of PCR amplification of eaeA gene in E. coli isolates (Fig. ,1) showed that, the eaeA gene was amplified in all four studied E. coli strains giving product of $248 \mathrm{bp}$. Similar findings were recorded by Kaper et al. (2004); Ayse et al. (2007); Ojo et al.(2010) and Bisi-Johnson et al.( 2011). Meanwhile, for $\beta$ lactamase ampicillin resistance (blaTEM) gene, the results of PCR amplification of blaTEM gene in E. coli isolates (Fig., 2) showed that, the blaTEM gene was amplified in all of the four studied E. coli strains giving product of $516 \mathrm{bp}$. Similar detection of blaTEM gene in E. coli strains were recorded by Colom et al. (2003); Sunde and Norstrom (2006); Van et al. (2008); Aslam et al. (2009); Ryu et al. (2012); Hemati et al. (2014) and Ahmed and Shimamoto (2015). For tetracycline resistant tetA (A)gene, the results of PCR amplification of $\operatorname{tet} \mathrm{A}(\mathrm{A})$ gene in E. coli isolates (Fig., 3) showed that, the tetA(A)gene was amplified in all four studied $E$. coli strains giving product of $576 \mathrm{bp}$.Similar detection of tet $\mathrm{A}(\mathrm{A})$ gene in $E$. coli strains were recorded by Randall et al. (2004); Sunde and Norstrom (2006); Van et al. (2008); Aslam et al. (2009); Gao et al. (2012); Momtaz et al. (2012) and Ryu et al. (2012). Moreover, for streptomycin resistant aada1 gene, the results of PCR amplification of aada1 gene in E. coli isolates (Fig. , 4) showed that, the aada 1 gene was amplified in all four studied E. coli strains giving product of $484 \mathrm{bp}$. Similar detection of aada 1 gene in $E$. coli strains were recorded by Randall et al. (2004); Sunde and Norstrom (2006); Van et al. (2008) ;Aslam et al. (2009) and Ryu et al. (2012).

Finally, the results proved that multiple antibiotic resistances are widely spread among isolated strains of E. coli and decided the fact of Shalini and Rameshwar (2005) that the food chain can be considered as the main route of transmission of antibiotic resistant bacteria between the animal and human populations. Therefore, it was concluded that; E. coli especially antibiotic resistances ones are meatborne pathogens of public health important.

\section{REFERENCES}

Abd El-Tawab,A.A., Maarouf,A.A., El-Hofy, Fatma, I. , El-Said, Aya, A. 2015. Bacteriological studies on some food borne bacteria isolated from chicken meat and meat products in Kaliobia 
Governorate. B.V.M.J., 29(2): 47-59.

Abdaslam, S. A.; Hassan, M. A.; Kaheel, H. A.;Abobaker, T. M.; Alnourain, T. H.; Hamdan, H. A.; Gokul Shankar, S. and Thambirajah, J. 2014. Isolation of Escherichia coli $\mathrm{O} 157$ and other food borne pathogens from meat products and their susceptibility to different antimicrobial agents. Current Research in Microbiology and Biotechnology, 2 (3): 391-397.

Abdel-Raouf, M.; Nabil, M. and El-Sayed, M. 2014. Antimicrobial Activities of Some Herbs Extracts on Food Borne Bacteria. J. American Science, 10 (11): 76-85.

Adwan, G. M.; Alqarem, B. R. and Adwan, K. M. 2015. Prevalence of foodborne pathogens in meat samples in Palestine. International food research J., 22(5):1806-1812.

APHA "American Public Health Association" 2001. Compendium of Methods for the Microbiological examination of Foods. $4^{\text {th }}$ Ed. F.P. Downes and K. Ito(editors), APHA. Washington D.C., USA.

Argudín, M.A.; Mendoza, M.C. and Rodicio, M.R. 2010. Food Poisoning and $S$. aureus enterotoxins. J. Toxins (Basel), 2(7):1751-1773.

Armany, A. G.; Ibrahim-Hemmat, M.; AminReham, A. and Ahmed-Hanaa, A. (2016): Detection of some foodborne pathogens in meat products by Polymerase Chain Reaction. Benha Vet. Med. J., 30( 1):323-330.

Arora, D. R. 2003. Cultural characteristics of Staphylococcus spp. Text Book of Microbiology. $2^{\text {nd }}$ Edition Publishing by Satish Kumar Jain for CBS publishers.

Bunnoeng, N.; Themphachana, M.; Pewleang, T.; Kongpheng, S.; Singkhamanan, K.; Saengsuwan, P. and Sukhumungoon, P. 2013. High prevalence and molecular characterization of methicillinresistant Staphylococcus aureus isolated from retailed meats, south Thailand. International Food Research J., 21(2): 569-576.

Carattoli, A. 2001. Importance of integrons in the diffusion of resistance. Veterinary Research, 32:243-259.

Chambers, H. F. and Deleo, F.R. 2009. Waves of resistance: Staphylococcus aureus in the antibiotic era. Nat. Rev. Microbiol., 7(9):629- 641.

Chen, H.; He, W.I.; Liu, Y.; Qi, I.; Zhao, C.; Zhang, F.; Li, I.F. and Wang, H. 2013. Food-animal related $S$. aureus multidrug-resistant ST9 strains with toxin genes. Foodborne Pathogen Dis., 10(9):782-788.

Ciftci, A.; Findik, A.; Onuk, A. and Savasan, S. 2009. Detection of Methicillin Resistance and Slime factor production of Staphylococcus aureus in bovine mastitis. Brazilian J. Microbiology, 40:254-261.

Courvalin, P. and Trieu-Cuot, P. 2001. Minimizing potential resistance: the molecular view. Clinical Infectious Disease, 33:138-146.

D'Costa, V.M.; McGrann, K.M.; Hughes, D.W. and Wright, G.D. 2006. Sampling the antibiotic resistome. Amer. Asso. Advan. Sci., 311:374-377.

Datta, S. A.;Akter, A.; Shah, I. G.; Fatema, K. ; Islam, T. H.; Bandyopadhyay, A.; Khan, Z. U. M. and Biswas, D. 2012. Microbiological quality assessment of raw meat and meat products and antibiotic susceptibility of isolated Staphylococcus aureus. J. Agric. Food Anal. Bacteriol., 2: 187-195.

Dinges, M.M.; Orwin, P.M. and Schlievert, P.M. 2000. Exotoxins of Staphylococcus aureus. Clinical Microbiology Reviews, 13(1): 16-34.

Eftekhar,F. and Dadaei,T. 2011. Biofilm Formation and Detection of IcaAB Genes in Clinical Isolates of Methicillin Resistant Staphylococcus aureus ranian .J. Basic Medical 
Sciences, 14(2): 132-136.

Ezzat, M.; Shabana, I. I.; Riad, E. M. and Sarah, M.A. 2014. Molecular characterization of Staphylococcus aureus isolated from meat, milk and their products. SCVMJ, XIX (1):137152.

FeBler, A.T.; Kadlec, K.; Hassel, M.; Hauschild, T.; Eidam, C.; Ehricht, R.; Monecke, S. and Schwarz, S. 2011. Characterization of methicillinresistant Staphylococcus aureus isolates from food and food products of poultry origin in Germany. Appl. Environ. Microbiol. , 77 (20): 71517157.

Gaafar, Rehab. E.M.;Ahmed ,A.M. Soliman,S.A. 2012. Spoilage bacteria in Frozen Meat Product. S.C.V. M.J.,XVII (1):97-108.

Ghenghesh K. S.; Ahmed S. F.; El-khalek R.A.; Al- Gendy, A. and Klena, J. 2008. Aeromonas- Associated infections in developing countries. J. Infect. Developing Countries, 2:81-98.

Gilbert, P. and McBain, A.J. 2003. Potential impact of increased use of biocides in consumer products on prevalence of antibiotic resistance. Clinical Microbiology Review, 16:189-208.

Hamed, E. A.; Ahmed,A.S. and Abd ElAaty,M.F. (2015): Bacteriological hazard associated with meat and meat products. Egypt. J. Agric. Res., 93, 4 (B): 385-393.

Ito, T.; Okuma, K.; Ma, M.; Yuzawa, H. and Hiramatsu, K. 2003. Insights on antibiotic resistance of $S$. aureus from its whole genome genomic island SCC. Microb. Drug. Resist.; 6:41-52.

Kalantari, S.; Sepehri, G.; Bahrampour, A. and Sepehri, E. 2012. Determination of bacterial contamination isolated from sandwiches in Kerman City and their resistance to commonly used antimicrobials, Arch. Appl. Sci. Reds., 4(2): 1100-1105.
Kelman, A.I.; Soong, Y.A.; Dupuy, N.; Shafer, D.; Richbourg, W.; Johnson, K.; Brown, T.; Kestler, E.; Li, Y.; Zheng, J.; McDermott, P. and Meng, J. 2011. Antimicrobial susceptibility of $S$. aureus from retail ground meats. J. Food Prot., 74(10): 16251629.

Khoramrooz, S.S.; Dolatabad,S.A.; Dolatabad, F.M.; Marashifard, M.; Mirzaii ,M.; Dabiri, H.; Haddadi ,A.; Rabani, S.M.;Shirazi, H.R.G. and DarbanSarokhalil, D. 2017. Detection of tetracycline resistance genes, aminoglycoside modifying enzymes, and coagulase gene typing of clinical isolates of Staphylococcus aureus in the Southwest of Iran. Iran J. Basic Med. Sci., 20(8):912-919.

Khosravi, A.D.; Jenabi, A. and Montazeri, E.A. 2017. Distribution of genes encoding resistance to aminoglycoside modifying enzymes in methicillin-resistant Staphylococcus aureus (MRSA) strains. Kaohsiung J. Med. Sci., 33(12):587-593.

Kolár, M.; Urbánek, K. and Látal, T. 2001. Antibiotic selective pressure and development of bacterial resistance. Int. J. Antimicrob. Agents, 17:357363.

Konemann, E.; Allen, S.; Janda, W.; Schreckenberger, C. and Winn, W. 1997. Color Atlas and Textbook of Diagnostic Microbiology. Fifth Edition. Lippincott, Philadelphia, New York.

Kukanich, B.; Gehring, R.; Webb, A. I.; Craigmill, A. I. and Riviere, J. E. 2005. Effect of formulation and route of administration on tissue residues and withdrawal times. J. A. M. Vet. Med. Assoc., 227: 1547-1577.

Lin, Y.C. and Peterson, M.L. 2010. New insights into the prevention of staphylococcal infections and toxic shock syndrome. Expert. Review of Clinical Pharmacology, 3(6): 753767. 
Llewelyn, M. and Cohen, J. 2002. Superantigens: Microbial agents that corrupt immunity. Lancet. Infect. Dis., 2: 156-162.

Maarouf, A. A. and Nassif-Marionette, Z. 2008. Bacteriological studies on frozen cow meat and some meat products at Benha city. J. the Egyptian Vet. Med. Assoc., 68 (1):129-141.

Martinez, J.L. and Baquero, F. 2002. Interactions among strategies associated with bacterial infection: pathogenicity, epidemicity, and antibiotic resistance. Clinical Microbiological Reviews, 15:647-679.

McMahon, M.A.S.; Blair, I.S.; Moore, J.E. and Mc Dowell, D.A. 2007. The rate of horizontal transmission of antibiotic resistance plasmids is increased in food preservation-stressed bacteria. J. Applied Microbiology, 103:18831888.

Mohamed, Hadeer, H.A. 2017. Bacteriological aspect of frozen beef burger. M. V. Sc. Thesis (Meat Hygiene), Fac. Vet. Med. Benha University.

Moroney, S.M.; Heller, L.C. and Widen, R.H. 2007. Staphylococcal Cassette Chromosome mec and PantonValentine Leukocidin Characterization of Methicillin-Resistant Staphylococcus aureus Clones. J. Clin. Microbiol., 45(3):1019-1021.

Mousa, M. M.; Ahmed, A. A. and El-Shamy, S. Y. 2014. Microbiological Criteria of Some Meat Products. Alexandria .J. Vet. Sci., 42 (1), 83-89.

NCCLS(2007 National committee for clinical laboratory standards guide line.

Park, K. Hae; Youn W. So; Jung, J.Y.; Eun, O. L.; Eun, C.J.; Park, S.H. and Sedng, J.L. 2008. Detection of Virulence Genes of S. aureus and S. epidermides isolated from Suprapubic Urine from Infants with Fever. J. Bacteriology and Virology, 38:189 - 196.

Plaatjies, Z.; Lues, J. and Buys, E. 2004. Staphylococcal growth in fresh vacuum-packed red meat at various storage conditions. $8^{\text {th }}$ World Congress on Environmental Health. Durban, South Africa.

Plata, K.; Rosato, AE. and Wegrzyn G. 2009. Staphylococcus aureus as an infectious agent: overview of biochemistry and molecular genetics of its pathogenicity. Acta Biochimica Polonica, 56(4):597-612.

Podkowik, M.; Bystro ń, J. and Bania, J. 2012. Genotypes, antibiotic resistance, and virulence factors of Staphylococci from ready-to-eat food. Foodborne Pathogens and Disease, 9: 91 - 93.

Prescott, M.; Harley, P. and Klein, D. A. (2005): Microbiology. $6^{\text {th }}$ Ed. McGraw Hill. New York U.S.A.: p. 910.

Protocarrero, S.;Newman, M. and Mikel, B .2002. S.aureus survival, Staphylococcal enterotoxin Production and shelf stability of country cured hams manufactured under different processing procedures . Meat Science. 62:267-273.

Quinn, P. J.; Markey, B. K.; Carter, M. E.; Donnelly, W. J. C.; Leonard, F. C. and Maguire, D. 2002. Veterinary microbiology and microbial disease. Iowa State Univ. Press, Blackwell Science Ltd, chapters 26-36: 84-96.

Rahimi, F. and Karimi, S. 2015. Characteristics of methicillin resistant Staphylococcus aureus strains isolated from poultry in Iran. Arch. Clin. Infect. Dis., 10(4):1-9.

Russell, A.D. 2001. Mechanisms of bacterial insusceptibility to biocides. American J. Infection Control., 29:259-261.

Safarpoor-Dehkordi, F.; Gandomi, H.; Basti , A.A.; Misaghi ,A. and Rahimi, E. 2017. Phenotypic and genotypic characterization of antibiotic resistance of methicillin-resistant Staphylococcus aureus isolated from from hospital food. Antimicrob Resist Infect Control. Oct 4;6:104

Sandel, M. K. and Mckillip, J. L. 2004. 
"Virulence and recovery of Staphylococcus aureus relevant to the food industry using improvements on traditional approaches". J. Food Control., 15:5-10.

Sambrook, J.; Fritsch, E.F. and Montias, T. 1989. Molecular Biology. In: Molecular cloning. Laboratory manual, Second Edition Cold Spring Harbor Laboratory press, USA.

Shalini, M. and Rameshwar, S. 2005. Antibiotic resistance in food lactic acid bacteria - a review". International J. Food Microbiology, 105:281-295.

Shea, K.M. 2004. Committee on Environmental Health and Committee on Infectious Disease: Non-therapeutic use of antimicrobial agents in animal agriculture: implications for pediatrics. Pediatrics, 114:862-868.
Tarabees, R. Z.; Hassanin,Z. H. and ElBagoury, A.M. 2015. Polymerase Chain Reaction (PCR): An Alternative Rapid Method for Detection of Some Microbial Contamination of Meat Products. Alexandria J. Veterinary Sciences, 45: 91-98.

Wehab, H. H. and Hegazy, S. K. S. 2007. Chemical and microbiological parameters of some food products from plant and animal protein origin. J. Egypt. Vet. Med. Assoc., 67 (2): $75-90$.

Zafar,A.; Ahmed, E.; Wajiha,H. and Khan,A. 2016. Microbiological Evaluation of Raw Meat Products Available in Local Markets of Karachi, Pakistan. Pakistan Academy of Sciences B. Life and Environmental Sciences 53 (2): 103-109. 